DOI: https://doi.org/10.32689/2523-4536/60-7

УДК 338.1:69.003.13

Метеленко Н. Г. доктор економічних наук, професор, завідувач кафедри інформаційної економіки, підприємництва та фінансів,

Інженерний навчально-науковий інститут Запорізького національного університету

Metelenko Natalia

Doctor of Economics, Professor, Head of the Department of Information economics,

Entrepreneurship and Finance

Engineering Educational-Scientific Institute of Zaporizhzhya National University

\title{
ПРОБЛЕМИ ТА ОРІЕНТИРИ РОЗВИТКУ ПІДПРИЄМСТВ БУДІВЕЛЬНОЇ ГАЛУЗІ В СУЧАСНИХ УМОВАХ ГОСПОДАРЮВАННЯ
}

\section{PROBLEMS AND GUIDELINES OF THE DEVELOPMENT OF CONSTRUCTION ENTERPRISES IN THE CURRENT CONTEXT OF ECONOMIC ACTIVITY}

\begin{abstract}
Дослідження спрямовано на розкриття проблем, з якими стикнулись вітчизняні підприємства будівельної галузі і підприємства суміжних галузей національної економіки України, що є замовниками або споживачами продукції будівниџтва. Обгрунтовано важливість ефективної роботи підприємств будівельної галузі для економіки в цілому. Наголошується на тому, що пошук механізмів підвищення ефективності функиіонування підприємств будівельної галузі ускладнюється в умовах сьогодення процесами посилення політичної та фінансової кризи в Україні, що також гальмуе розвиток інтеграційних процесів до європейського економічного простору. Окреслено вирішальну роль створення сприятливого інвестиційного підприємнищького клімату, послідовний перехід від вітчизняних до європейських стандартів у будівниитві, реформування законодавчої та нормативно-правової бази в галузі. За офіційними даними Державної служби статистики України проаналізовано динаміку обсягів виробленої будівельної продукиії та обгрунтовано тендениії і наслідки змін в галузі. Доведено, що ефективність роботи підприємств будівельної галузі залежсть від низки чинників, які є спещифічними для підприємств цієї галузі, до основних з таких чинників віднесено: використання будівельної продукиії можливе лише за місием ії виробництва та існуе значна залежність галузі від природних факторів, що у випадку незапланованих подій негативно позначається на тривалості технологічного иииклу та призводить до додаткових втрат ресурсів; особливості тимчасової взаємодії між підприємствами і організачіями різних галузей начіональної економіки під час створення будівельної продукиії викликає необхідність техніко-економічних та техніко-технологічних внутрішньогалузевих та міжгалузевих зв'язків. Наголошується, що систематизовані характерні ознаки галузі є передумовами, на яких повинна трунтуватись антикризова стратегія розвитку підприємств, яка визначає пріоритетні напрями розвитку та механізм їхнього фінансування. Здійснено аналіз структури джерел фінансування капітальних інвестииій в Україні. Доведено складність умов функціонування будівельних підприємств, що підвищує відповідальність $і$ самостійність у прийнятті управлінських рімень щодо забезпечення ефективності їх господарської діяльності в сучасних умовах інтеграиії до СС. Окреслено орієнтири розвитку будівельних підприємств з урахуванням тендениій, що склались у галузі та економіці України в иілому, що у подальшому дозволить сформувати антикризову стратегію розвитку галузі, спрямовану на інтеграцію вітчизняної економіки до європейського економічного простору.
\end{abstract}

Ключові слова: будівельна галузь, будівельні підприємства, стратегічні орієнтири, інвестиційний підприємницький клімат, технологічний циикл, капітальні інвестищії.

The study was aimed at revealing the problems were faced by domestic enterprises of the construction industry and enterprises of related industries of the national economy of Ukraine, which are customers or consumers of construction products. The importance of efficient work of construction enterprises for the economy as a whole was substantiated. It was emphasized that the search for mechanisms to improve the efficiency of the construction industry is complicated nowadays by processes of intensification of the political and financial crisis in Ukraine, which also are slowing down the development of integration processes into the European Economic Area. The decisive role of creating a favorable investment business climate, the consistent transition from domestic to European 
standards in construction, the reforming the legislative and regulatory framework in the industry have been defined. According to the official data of the State Statistics Service of Ukraine, the dynamic of the volume of construction products was analyzed and the trends and consequences of changes in the industry were substantiated. It was proved that the efficiency of construction enterprises depends on a number of factors that are specific to enterprises in this industry, the main of these factors are: the use of construction products is possible only at the place of its production and there is a significant dependence of the industry on natural factors that in case of the unplanned events have negative affect to the duration of the technological cycle and lead to additional loss of resources; features of temporary interaction between enterprises and organizations of different sectors of the national economy during the creation of construction products necessitates technical-economic and technical-technological intra-and inter-industry links. It was emphasized that the systematized characteristics of the industry are the prerequisites on which the anti-crisis strategy of enterprise development should be based, which determines the priority directions of development and the mechanism of their financing. The analysis of the structure of sources of financing of capital investments in Ukraine was carried out. The complexity of the conditions of operation of construction enterprises was proved, which increases the responsibility and independence in making management decisions to ensure the efficiency of their economic activities in the current conditions of integration into the EU. The guidelines for the development of construction enterprises were outlined, taking into account the current trends in the industry and the economy of Ukraine as a whole, which will further form an anti-crisis strategy for the development of the industry aimed at integrating the domestic economy into the European Economic Area.

Keywords: construction industry, construction enterprises, strategic guidelines, investment business climate, technological cycle, capital investments.

Постановка проблеми. Дослідження процесів поширення кризових явищ в економіці України, які супроводжуються підвищеним ступенем невизначеності будь-яких подій у суспільстві, свідчить про потребу подальшого розвинення наукового бачення розвитку будівельної галузі як невід'ємної складової промислового комплексу України. Будівельна галузь тісно пов'язана 3 іншими стратегічними галузями національної економіки, такими як машинобудування, металургійна галузь, електроенергетика, тому кризові явища у будівництві гальмують розвиток економіки за рахунок уповільнення будови виробничих потужностей, складських та офісних приміщень, логістичних та інженерних мереж, обладнання тощо. За таких умов промислові підприємства окреслених галузей потребують впровадження дієвих механізмів відновлення ефективності їх функціонування, упередження кризових явищ та моніторингу макроекономічної ситуації, яка безпосередньо впливає на дієздатність механізму функціонування підприємства. Пошук механізмів підвищення ефективності функціонування підприємств будівельної галузі ускладнюється посиленням політичної та фінансової кризи в економіці України.

Мета дослідження - дослідити тенденції функціонування будівельної галузі та обгрунтувати пріоритетні орієнтири розвитку підприємств будівельної галузі з урахуванням сучасних умов господарювання.

Аналіз останніх досліджень і публікацій, в яких започатковано розв'язання даної проблеми. Важливість будівельної галузі для економіки будь-якої країни можна пояснити таким:

- наявність капітального будівництва створює велику кількість робочих місць, що покращує соціально-економічний стан в регіоні та країні в цілому;

- галузь будівництва використовує продукцію багатьох галузей національної економіки, що викликає мультиплікативний економічний ефект;

- 3 розвитком будівельної галузі розвивається виробництво будівельних матеріалів, обладнання, машинобудівна галузь, металургія та металообробка, деревообробна галузь, нафтохімічна галузь, транспортна галузь, електроенергетика тощо.

- будівництво сприяє розвитку малого та середнього бізнесу.

Сучасні реалії свідчать про загострення протиріч в економічній системі держави, що веде до погіршення фінансового стану та ефективності функціонування, зокрема, i будівельних підприємств.

Актуальність питання підвищення ефективності функціонування будівельних підприємств посилюється вимогами $Є С$, які висувають наші партнери, та які необхідно виконувати згідно Угоди про асоціацію між Україною та СС. Для виходу на європейський рівень Україні необхідно створення сприятливого інвестиційного підприємницького клімату, послідовний перехід від вітчизняних до європейських стандартів.

Вагомий внесок у вирішення окремих проблемних аспектів діяльності та розвитку підприємств будівельної галузі зробили такі науковці - економісти, як М.А. Окландер, Л.О. Богінська, В.Ю. Божанова, С.С. Масюк, Г.Л. Ступкінер, М.В. Чорна, С.В. Глухова, Т.П. Норкіна, О.В. Якименко та ін.

Виклад основного матеріалу дослідження 3 повним обгрунтуванням отриманих наукових результатів. Сьогодні загальні тенденції функціонування галузі свідчать про 
відсутність дієвої стратегії розвитку галузі (табл. 1). Так, динаміка обсягів виробленої будівельної продукції в період 2014-2019 рр. [1] показує, що:

- темп росту будівництва житлових будинків у 2019 р. склав 113,17\%, що навіть нижче за показник 2015 р.;

- темп росту будівництва нежитлових будинків у 2019 р. становив 134,54\%, тобто знизився до рівня 2016 р.;

- низькі обсяги виробництва продукції транспортних споруд (залізниця) впродовж всього періоду, що аналізується, свідчать про відсутність стратегічної програми розвитку галузі в цьому напрямі;

- звертає на себе увагу тенденція виконання короткострокових робіт, наприклад ремонтних, та практично відсутність довгострокових проєктів; так, обсяг вкладень на місцеві трубопроводи та комунікації практично співпадає з обсягом вкладень на виробництво магістральних трубопроводів, комунікацій та ліній електропередач; це є свідченням низької активності капітальних вкладень у галузі.

Ефективність роботи підприємств будівельної галузі, як свідчить аналіз праць [2-7] залежить від низки чинників, які є специфічними для підприємств цієї галузі, а саме:

- використання будівельної продукції можливе лише за місцем її виробництва;

- існує прямий зв'язок між об'єктом виробництва будівельного підприємства та об'єктом земельних відносин;

- існує значна залежність від природних факторів, що може суттєво позначитись на тривалості технологічного циклу;

- низька швидкість обороту капіталу не надає змогу мобільно маневрувати коштами, що перебувають у господарському обороті підприємства;

- високовартісний характер об'єктів будівництва та тривалість технологічного циклу вимушує підприємства залучати фінансові ресурси у вигляді авансових платежів або кредитних ресурсів;

- зміна тривалості технологічного циклу будівельних робіт негативно впливає на продуктивність праці;

- існує особливості тимчасової взаємодії між багатьма підприємствами і організаціями під час створення будівельної продукції, що викликає наявність складних техніко-економічних та техніко-технологічних зв'язків між підприємствами галузі та 3 підприємствами суміжних галузей;

- багаточисельність, різноманітність, складність нормативної та іншої документації викликає потребу спеціальної підготовки до iii опрацювання та високу ймовірність впливу людського фактору, що веде до зниження якості вихідної інформації та до непрозорості процедур.

Систематизація наведених характерних ознак діяльності будівельних підприємств, тенденції зміни макроекономічних показників у галузі надають змогу стверджувати, що підприємства будівельної галузі потребують розробки антикризової стратегії розвитку, яка повинна гуртуватись на визначенні, з одного боку, пріоритетних напрямів розвитку, а 3 іншого боку - на розробці механізму фінансування цих пріоритетних напрямів. Характерні ознаки діяльності будівельних підприємств $\epsilon$ передумовами побудови антикризової стратегії розвитку.

Слід зауважити, що сьогодні структура джерел фінансування (табл. 2) капітальних інвестицій в Україні зазнала деяких змін, a саме:

- структура джерел 2019 р. у порівнянні 3 минулими 2013 - 2018 рр. характеризується зростанням питомої ваги коштів державного бюджету, що виділено на капітальне інвестування - 4,94\% у 2019 р. проти 1,25\% у 2014 р.;

- за рахунок подальшого розвитку процесів децентралізації відбувається накопичення коштів місцевих бюджетів та спрямування ïx на потреби регіонів, зокрема, питома вага коштів місцевих бюджетів, що виділено на капітальне інвестування у 2019 р. становить 9,05\% у 2019 р. проти 2,7\% у 2014 р.;

- питома вага власних коштів підприємств та організацій, що виділено на капітальне інвестування у 2019 р. Знизилась та склала 65,43\% у 2019 р. проти 70,47\% у 2014 р., що свідчить про негативні тенденції уповільнення розвитку економіки; як наслідок - знижується інвестиційна активність інвесторів - нерезидентів, питома вага коштів яких у процеси капітального інвестування в економіку України у 2019 р. склала 0,75\% проти 2,57\% у 2014 p.;

- кризові явища в економіці та зниження рівня життя населення призвели до падіння інвестування коштів на будівництво житла 3 $10,06 \%$ у 2014 р. до $5,2 \%$ у 2019 р.

Складність умов функціонування будівельних підприємств підвищує відповідальність і самостійність у прийнятті управлінських рішень щодо забезпечення ефективності їх господарської діяльності. Прийняття цих рішень залежить від чинників, що взаємодіють на різних рівнях як між собою, так і між показниками кінцевої ефективності діяльності будівельних підприємств, які функціо- 


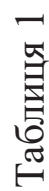

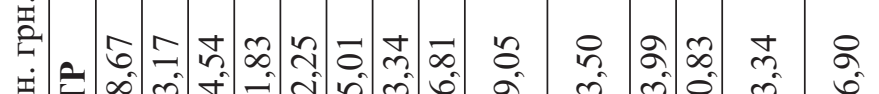

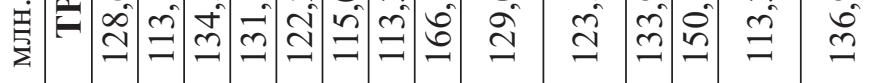

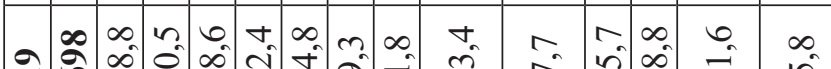

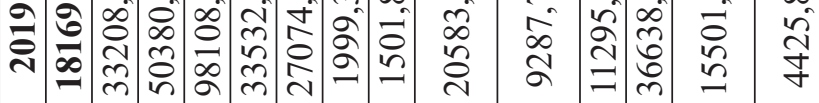

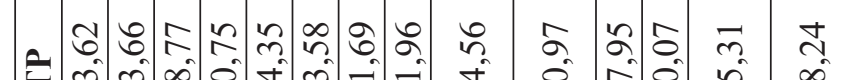

官

iี

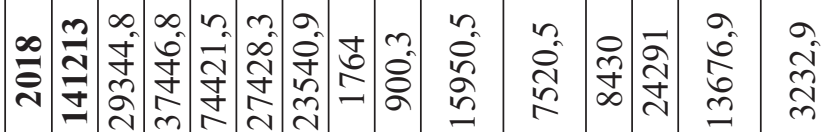

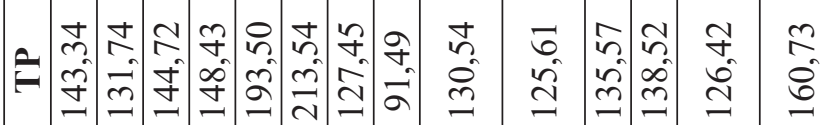

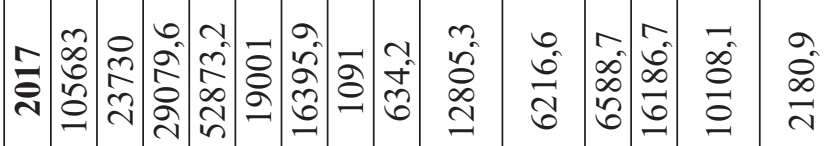

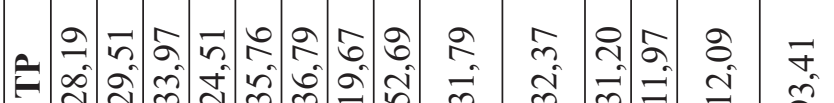

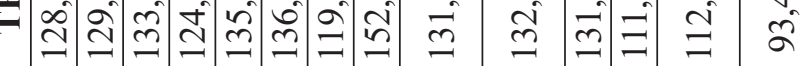

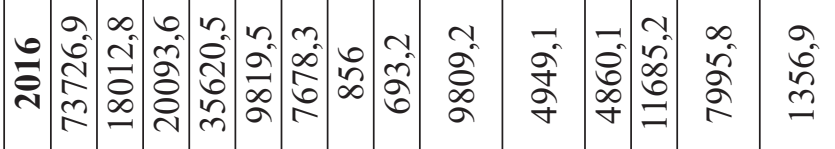

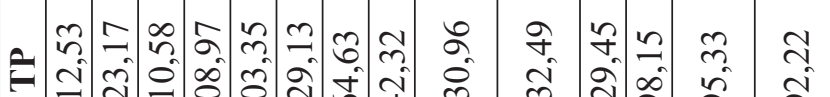

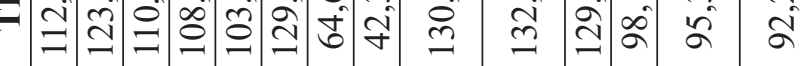

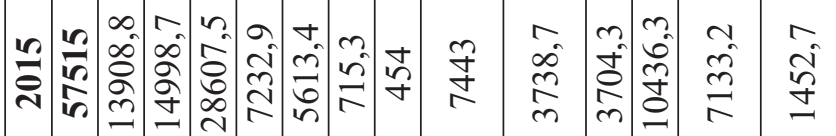

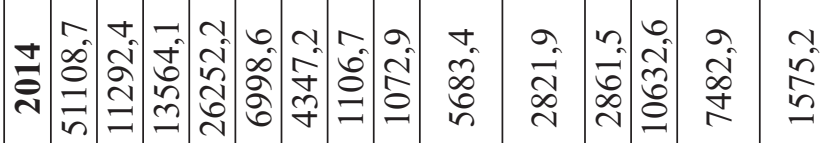

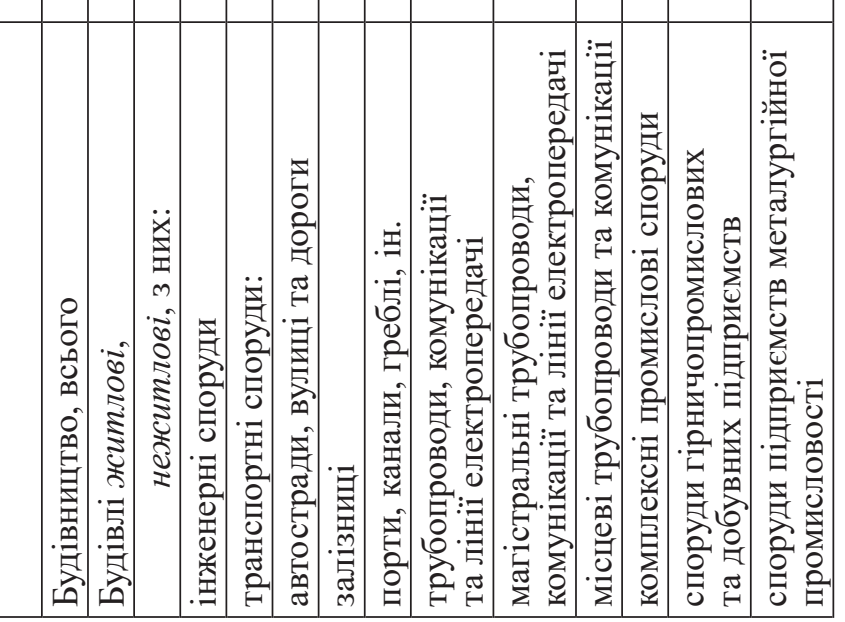

焉

\begin{tabular}{|c|c|c|c|c|c|c|}
\hline & J & $\left|\begin{array}{l}n \\
0 \\
0\end{array}\right|$ & $\begin{array}{l}\tilde{\sigma} \\
\tilde{b}\end{array}$ & $\stackrel{\hat{n}}{0}$ & $\frac{n}{0}$ & $\begin{array}{l}\text { त̂ } \\
\text { ni }\end{array}$ \\
\hline 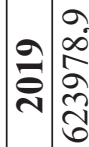 & & 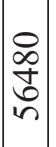 & $\begin{array}{l}\hat{n} \\
\hat{a} \\
o \\
o \\
o\end{array}$ & 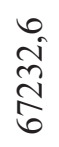 & 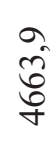 & 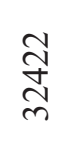 \\
\hline$=$ & & $\stackrel{R}{1}$ & $\stackrel{\hat{\imath}}{i}$ & $\stackrel{n}{i}$ & $\vec{m}$ & $\begin{array}{l}2 \\
\text { n. }\end{array}$ \\
\hline
\end{tabular}

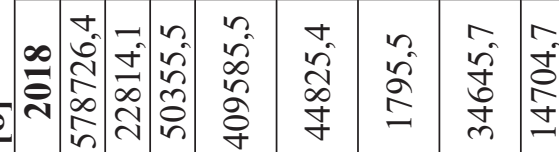

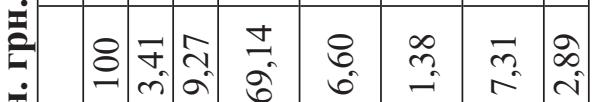

$\dot{\mathrm{E}}$

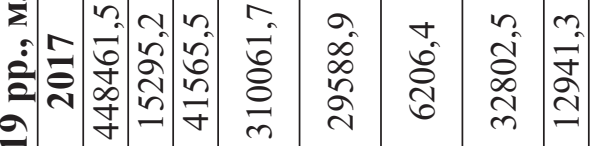

กั่

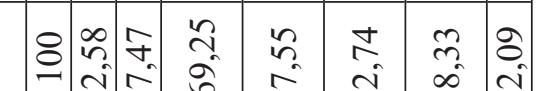

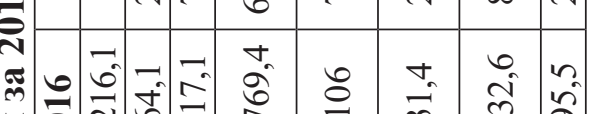

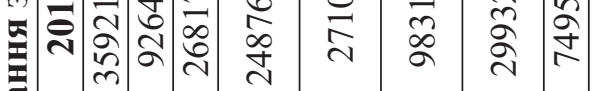

苞

\& กิ

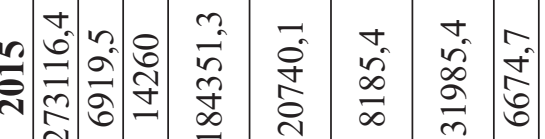

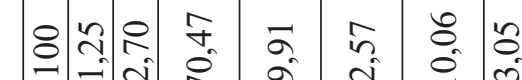

m

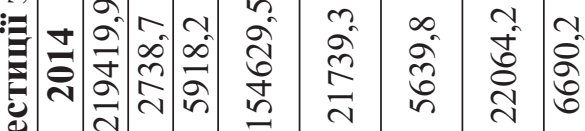

(1)

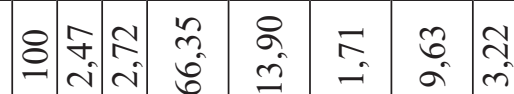

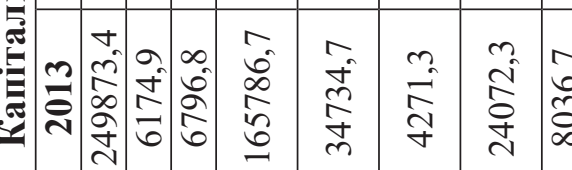

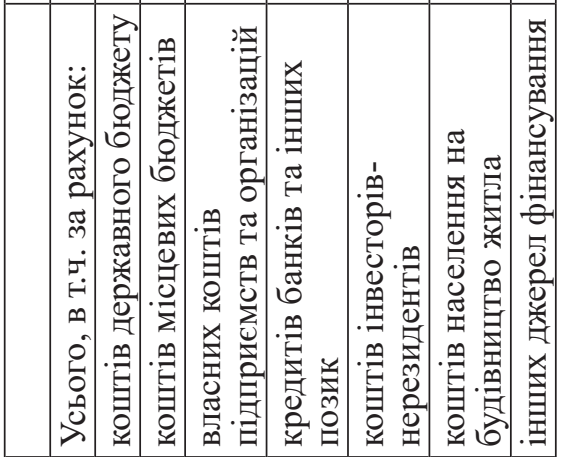


нують в мінливих, у більшості невизначених умовах господарювання та орієнтовані на подальшу інтеграцію з СС.

Проведене дослідження надає змогу окреслити орієнтири розвитку будівельних підприємств $з$ урахуванням тенденцій, що склались у галузі та економіці України в цілому:

- усвідомлення того, що пріоритетним способом організації бізнесу підприємствами галузі будівництва в Україні є спільне підприємництво на основі об'єднання зусиль вітчизняних та зарубіжних інвесторів (за умови покращення інвестиційного клімату в Україні);

- уніфікація норм діючого українського законодавства в галузі будівництва до європейських норм 3 метою інтеграції процесів ведення бізнесу та залучення іноземних інвесторів;

- активізація впровадження сучасних технологій у будівництві (за умови реалізації вище окреслених напрямів розвитку);

- подальший розвиток інженерних спеціальностей галузі будівництво (192. Будівництво та цивільна інженерія), що метою підвищення якості освітньо-фахового потенціалу персоналу будівельних підприємств;

- удосконалення організації ефективних та результативних форм взаємодії в системі «бізнес - держава - наука» не тільки в галузі будівництва, а у всіх галузях економічної діяльності тому, що саме міжгалузева взаємодія надає можливість отримати синергетичний ефект зростання економіки.

Погоджуючись з авторами [9], слід додати, що ретельне вивчення сучасних умов функціонування будівельних підприємств в Україні, дослідження макроекономічного середовища, впровадження досвіду функціонування галузі в країнах $\mathrm{CC}$, удосконалення державного регулювання будівельного ринку сформують стратегічні орієнтири розвитку підприємств будівельної галузі в Україні в сучасних умовах господарювання та інтеграції вітчизняної економіки до європейського економічного простору.

Висновки і перспективи подальших досліджень. Окреслені орієнтири розвитку будівельних підприємств, що враховують тенденції, які склались у галузі та економіці України в цілому; систематизація характерних ознак діяльності підприємств будівельної галузі; визначення пріоритетних напрямів розвитку та розробка механізму фінансування цих напрямів $\epsilon$ організаційно-економічним підгрунтям для розробки у подальших дослідженнях антикризової стратегії розвитку, яка повинна передбачати, поряд з іншим, заходи державної підтримки галузі.

\section{Список використаних джерел:}

1.Державна служба статистики України. Обсяг виробленої будівельної продукції за видами у 2014-2019 роках. URL: http://www.ukrstat.gov.ua/ (дата звернення 19.08.2020).

2.Економіка будівельного підприємства : підручник / авт. кол. : Т.О. Окландер, І.А. Педько, О.Л. Камбур [та ін.]. Київ : Центр учбової літератури, 2018. 363 с.

3.Богінська Л.О. Економічні засади формування та використання ресурсного потенціалу будівельного підприємства. Науковий вісник Ужгородського університету. Серія: Економіка. 2016. Вип. 1 (47), T. 2. C. 316-320.

4.Божанова В.Ю., Ступнікер Г.Л., Масюк С.Є. Методичні підходи до формування антикризової стратегії розвитку будівельних підприємств в сучасних умовах. Економічний простір. 2013. № 78. C. 214-223.

5.Чорна М.В., Глухова С.В. Стратегічні напрями інноваційної діяльності підприємств будівельної галузі. Економічна стратегія і перспективи розвитку сфери торгівлі та послуг. 2012. Вип. 1 (1). C. $210-216$.

6.Норкіна Т.П., Скарбун 3.О. Удосконалення управління інноваційним розвитком підприємств будівельної галузі. Економіка будівництва і міського господарства. 2013. Т. 9, № 1. С. 55-62.

7.Якименко О.В. Вплив інноваційного потенціалу на розвиток будівельних підприємств. Збірник наукових прачь ВНАУ. Серія: Економічні науки. 2013. № 4 (81). С. 316-325.

8.Державна служба статистики України. Капітальні інвестиції за джерелами фінансування за 2010-2019 роки. URL: http://www.ukrstat.gov.ua/ (дата звернення 19.08.2020).

9.Ліпич Л.Г. ,Чорнуха I.В., Цимбалюк I.О. Формування стратегії розвитку будівельного підприємства в умовах інвестиційної конкуренції : [монографія]. Луцьк : Вежа-Друк, 2015. 212 с.

\section{References:}

1.The official site of The State Statistics Service of Ukraine "The volume of construction products produced by type in 2014-2019". Available at: http://www.ukrstat.gov.ua/ (accessed 19 August 2020).

2.Oklander T.O., Pedko I.A., Kambur O.L. (2018) Ekonomika budivelnoho pidpryiemstva [Economy of the construction enterprise]. Kyiv: Center for Educational Literature. (in Ukrainian) 
3.Bohinska L.O. (2016) Ekonomichni zasady formuvannia ta vykorystannia resursnoho potentsialu budivelnoho pidpryiemstva [Economic principles of formation and use of resource potential of a construction enterprise]. Scientific Bulletin of Uzhhorod University. Series: Economy, vol. 1 (47), no. 2, pp. 316-320.

4.Bozhanova V.Yu., Stupniker H.L., Masiuk S.Ye. (2013) Metodychni pidkhody do formuvannia antykryzovoi stratehii rozvytku budivelnykh pidpryiemstv v suchasnykh umovakh [Methodical approaches to the formation of anti-crisis strategy for the development of construction enterprises in the current context]. Economic space, no. 78 , pp. 214-223.

5.Chorna M.V. (2012) Stratehichni napriamy innovatsiinoi diialnosti pidpryiemstv budivelnoi haluzi [Strategic directions of innovative activity of enterprises of construction industry]. Economic strategy and prospects of the development of sphere of trade and services, vol. 1, no. 1, pp. 210-216.

6.Norkina T.P. (2013) Udoskonalennia upravlinnia innovatsiinym rozvytkom pidpryiemstv budivelnoi haluzi [Improvement of the management of innovative development of enterprises of construction industry]. Economics of construction and urban economy, vol. 9, no 1, pp. 55-62.

7.Yakymenko O.V. (2013) Vplyv innovatsiinoho potentsialu na rozvytok budivelnykh pidpryiemstv [The impact of innovation potential to the development of construction enterprises]. Collection of scientific works of VNAU. Series: Economic Sciences, no. 4 (81), pp. 316-325.

8.The official site of The State Statistics Service of Ukraine "Capital investments by sources of financing for 2010 - 2019". Available at: http://www.ukrstat.gov.ua/ (accessed 19 August 2020).

9.Lipych L.H. (2015) Formuvannia stratehii rozvytku budivelnoho pidpryiemstva v umovakh investytsiinoi konkurentsii [Formation of strategy of development of the construction enterprise in the conditions of investment competition]. Lutsk: Vezha-Druk. (in Ukrainian) 